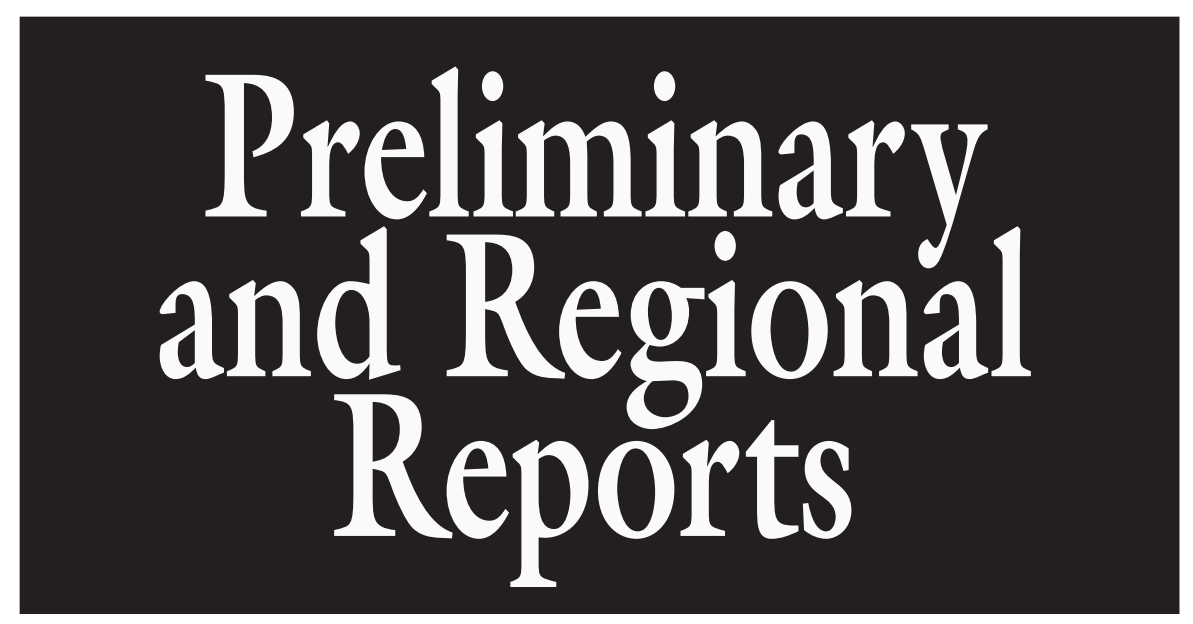

\section{Preliminary Studies on Propagation of Osha}

\author{
Karen L. Panter, ${ }^{1}$ \\ Rebecca E. Ashley, ${ }^{2}$ \\ Karin M. Guernsey, ${ }^{3}$ and \\ Caroline M. Johnson ${ }^{4}$
}

Additional INDEX WORDS. Ligusticum porteri, seed propagation, cuttings, vegetative propagation, stratification, native plants, medicinal herbs

\section{Summary. Osha (Ligusticum porteri) is a perennial plant native to the Rocky Mountain region of the United States and has been used as a medicinal herb to alleviate certain ailments caused by viruses, yeasts, and other microbes. It is generally harvested in the wild and is believed to be in danger of over- harvest. The objectives of this study were to determine if osha could be grown successfully from seeds, seeds}

University of Wyoming Agricultural Experiment Sta tion Report number JA1787. The authors thank the Small Business Innovation Research group for funding this project. We also thank Annette Miller and Leigh Towill, USDA-ARS National Center for Genetic Resources Preservation, Fort Collins, Colorado, for seed viability testing and manuscript review, respectively; Kim Vincent, formerly of the Small Business Develop ment Center, University of Wyoming, Laramie, for her assistance in grant procurement and administration; and David Legg, Department of Renewable Resources, University of Wyoming, Laramie, for assistance with data analysis. Recognition is due to Mr. Shawn Sigstedt for his pioneering work in cultivating osha.

${ }^{1}$ Horticulture specialist, College of Agriculture-Plant Sciences, Dept. 3354, 1000 E. University Ave., University of Wyoming, Laramie, WY 82071.

${ }^{2}$ Undergraduate research assistant, College of Agricul ture-Plant Sciences, Dept. 3354, 1000 E. University Ave., University of Wyoming, Laramie, WY 82071.

${ }^{3}$ Owner, Elk Mountain Herbs, 214 Ord Street, Laramie, WY 82070.

${ }^{4}$ Owner, Aspen Grove Ranch, Elk Mountain, WY 82324. still attached to umbels, root cuttings, and/or vegetative crown cuttings. Seeds were harvested from the wild in Fall 2000. Roots were collected in May 2001. Seeds, either detached or attached to umbels, were given one of four treatments: 1) no stratification; 2) 6 weeks at $\left.4.4^{\circ} \mathrm{C}\left(40{ }^{\circ} \mathrm{F}\right) ; 3\right) 4$ weeks each alternating $4.4^{\circ} \mathrm{C}$, then 12 hour $20.0^{\circ} \mathrm{C}\left(68^{\circ} \mathrm{F}\right)$ and 12 hours 30.0 ${ }^{\circ} \mathrm{C}\left(86^{\circ} \mathrm{F}\right)$; or 4$) 12$ weeks at $4.4^{\circ} \mathrm{C}$. Roots were divided into crown cuttings, each containing a vegetative node, and were placed on a $21.1^{\circ} \mathrm{C}\left(70^{\circ} \mathrm{F}\right)$ mist propagation bench until rooted. Twelve weeks of stratification, whether seed was detached or attached to umbels, were beneficial for germination of osha seeds, but only gave about $11 \%$ emergence. Propagation from root cuttings was not successful. Propagation via vegetative crown cuttings was most successful, with $90 \%$ of cuttings rooting. Vegetative propagation of osha appears to be the most promising method, preferable over seed propagation.

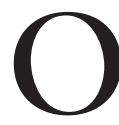
sha is a popular medicinal perennial plant native to the Rocky Mountain region (Dorn, 1992). It is a member of the Apiaceae family along with carrot (Daucus carota), arracacha (Arracacia xanthorrhiza), and lovage (Levisticum officinale) (Rubatzky et al., 1999). Over the last 20 years, the root of the osha plant has gained a reputation as a fast acting, effective medicine (Bergner, 1994; Moore, 1995; Zand et al., 1994). Ligustilide, an active ingredient found in the root, displays weak antiviral properties and weak antimicrobial activity against gram-positive, gram-negative, and yeast microorganisms (Beck and Stermitz, 1995; Gillespie, 1996, 1998). This popularity is demonstrated by the amounts of osha root sold by Frontier Natural Foods Cooperative (Norway,
Iowa) since 1996: $272.2 \mathrm{~kg}(600 \mathrm{lb})$ in 1996, and $598.8 \mathrm{~kg}$ (1320 lb) in 1999 (B. Lechworth, personal communication).

Osha is harvested in the wild, and since the entire root is of medicinal interest, it is probable that all plant material from a site may be removed (University of Maryland, 1999). Of particular concern is the fact that roots are often $\geq 10$ years old when harvested. Over-harvesting in the wild would lead to long-term loss of wild root stock. A national organization, United Plant Savers, monitors native medicinal plant populations and has listed osha as an at-risk plant (United Plant Savers, 2000). Osha is also considered a species of concern by the Plant Conservation Alliance (2000). If osha can be grown commercially, growers would have another crop to add to their product mixes and danger of over-harvest in the wild would be reduced.

Little information, other than anecdotal, is available on propagation methods for osha. Propagation efforts have been minimal due to perceived difficulty of seed germination and few, if any, have tried vegetative propagation (Plant Conservation Alliance, 2002; University of Maryland, 1999). However, carrot, arracacha, and lovage, relatives of osha, can be propagated from crown cuttings or divisions (Rubatzky et al., 1999). Inversion of umbels with seeds still attached may be a viable means of germinating osha seed, in part because flowering stalks in the wild may be broken or bent over allowing umbels to come in contact with the ground. Our objectives were to use generally accepted plant propagation principles to determine if osha could be grown successfully from detached seeds, seeds attached to umbels, root cuttings, and/ or vegetative crown cuttings.

\section{Materials and methods}

Seed propagation. Seed propagation tests were set up as two experiments: Expt. 1 involved detached seeds while Expt. 2 used seeds still attached to umbels. Each experiment used a factorial combination of four cold treatments and two germination techniques and was analyzed as a completely randomized design. Each of the eight treatment combinations consisted of two 27.9 $\times 27.9-\mathrm{cm}(11$-inch $)$ plastic trays with 25-mL (0.85-fl oz) cells. Germination medium used for both experiments was a commercial mix specifically formulated 
for propagation (Superfine Germinating Mix; Conrad Fafard, Inc., Agawam, Mass.). The mix contains fine particles of peat moss, vermiculite, and perlite.

The four cold treatments were as follows:

1) Control: no cold, moist stratification. Seed trays were placed on a $21.1{ }^{\circ} \mathrm{C}$ propagation bench, under natural light and daylength, or in a germination chamber, in the dark, alternating $12 \mathrm{~h}$ of $30.0^{\circ} \mathrm{C}$ with 12 h $20.0^{\circ} \mathrm{C}$ until seedling emergence. Treatments 2,3 , and 4 were undergoing stratification during this time.

2) Six weeks cold, moist stratification at $4.4{ }^{\circ} \mathrm{C}$.

$3)$ Four weeks cold, moist stratification at $4.4{ }^{\circ} \mathrm{C}$ followed by transfer to a germination chamber for 4 weeks alternating $12 \mathrm{~h} 30.0^{\circ} \mathrm{C}$ with $20.0^{\circ} \mathrm{C}$. The original intent was for another 4 weeks of cold stratification at 4.4 ${ }^{\circ} \mathrm{C}$. However, seedlings emerged in trays during this second phase and another cold treatment in the cooler was not pursued.

4) Twelve weeks cold, moist stratification at $4.4{ }^{\circ} \mathrm{C}$.

The two germination techniques following cold treatment above were as follows:

1) Germination chamber in the dark alternating $12 \mathrm{~h}$ at $30.0^{\circ} \mathrm{C}$ with 12 h at $20.0^{\circ} \mathrm{C}$

2) Mist propagation bench under natural light and daylength at $21.1^{\circ} \mathrm{C}$.

The germination chamber temperatures were chosen in accordance with Ellis et al. (1985) who indicated this temperature regime as optimum for germination of seeds for many Apiaceae family members. Trays were kept under each germination technique until seedling emergence.

Expt. 1: Detached seeds. Dry, unimbibed seeds were collected from a wild stand of osha near Elk Mountain, Wyo., in October 2000. Seeds were kept dry, in closed plastic bags, and were stored in a $4.4^{\circ} \mathrm{C}$ cooler until sown in May 2001. Relative humidity in the cooler was not monitored. Generally, temperatures of $4.4^{\circ} \mathrm{C}$ to $10.0^{\circ} \mathrm{C}\left(50^{\circ} \mathrm{F}\right)$ are adequate for short term storage of most dry seeds. For example, seeds of carrots, close relatives of osha, can be stored under these conditions for up to 3 years (Maynard and Hochmuth, 1997).

In April 2001, viability tests using tetrazolium reduction were conducted on the stored detached seeds. Two 100seed lots of detached seeds were tested at the USDA-ARS National Center for Genetic Resources Preservation in Fort Collins, Colo. The seed lots contained $47 \%$ and $49 \%$ viable seeds, respectively.

On 14 May 2001, seeds were sown two percell (due to $48 \%$ viability) in previously described trays. Three batches of 16 cells ( 32 seeds) each were sown, uncovered, in each tray, with each tray considered a replication. Treatments began immediately after sowing. During stratification and in the germination chambers, trays were misted as needed with deionized water to keep the germination medium moist.

EXPT. 2: SeEdS ATTAChed to Umbels. Umbels were collected at the same time and location as detached seeds and were stored until May 2001 under the same conditions. On 14 May 2001 intact umbels were inverted onto $27.9 \times 27.9-\mathrm{cm}$ open trays (no cells) containing propagating medium. Seeds were uncovered but in contact with the medium. Seeds per umbel were counted before placement in trays. Seed numbers per umbel were highly variable ranging from 9 to 241 with an overall mean of 49.6 (SD $=36.5$ ) seeds per umbel. Four umbels were inverted on each tray, with each tray as a replication. Treatments (same as for seeds above) began immediately after inversion. Trays were periodically misted in the cooler and germination chamber to minimize drying out.

Germination techniques. After cold treatments, two trays of each were placed on the mist propagation bench and two were placed in the germination chamber until seedling emergence.

Data on seedling emergence were taken daily and data collection was completed by 16 Aug. 2001.

Data collection and analysis. Percent emergence was determined for Expts. 1 and 2. Due to unequal variances and non-normal data distributions, these data were converted three ways: arcsine transformed, transformed and weighted, and neither transformed nor weighted. Data were analyzed using the General Linear Models Analysis of Variance program of the Statistical Analysis System (SAS Institute, Inc., Cary, N.C.) and included checks for interactions between the factors of cold, moist stratification treatment and germination technique. Percent emergence mean separations were conducted using Fischer's least significant difference at $P \leq 0.05$. No differences in treatment significance were apparent with the three methods. Consequently, results are reported using untransformed and unweighted data.

Vegetative PROPAGATION-EXPT. 3: Crown cuttings. Crown cuttings of osha were taken 24 May 2001 from plants dug in early May 2001 from a native stand near Elk Mountain, Wyo. Forty-eight crown cuttings (containing a portion of both root and stem) were removed from the plants. Osha roots are fleshy taproots with multiple crowns and several crown cuttings could be prepared from each storage organ. Cuttings were stuck in germinating medium in two $27.9 \times 55$.9$\mathrm{cm}(11 \times 22$-inch $)$ trays, 24 cuttings per tray. Trays were placed on the same mist propagation bench as was used for seeds above. No treatments were conducted; percent rooting was determined for all 48 cuttings.

Vegetative propagation-Expt. 4: Root Cuttings. Osha's storage root also produces lateral fibrous roots. At the same time as Expt. 3, 24 root sections, each $7.6 \mathrm{~cm}$ (3 inches) long and $\approx 3 \mathrm{~mm}$ (0.12 inch) in diameter, were cut and placed in a $27.9 \times 27.9-\mathrm{cm}$ tray. These were covered with germination medium and then were placed on the mist propagation bench for root formation. No treatments were performed on root cuttings; percent root/shoot development was determined for all 24 root cuttings.

\section{Results}

Seed propagation-Expt. 1: DeTACHED SEEDS. There was no interaction between cold, moist stratification treatment and germination technique (Table 1). There were differences among cold, moist stratification treatments. Twelve weeks of stratification produced the largest percent of seedling emergence among the treatments. The percentage was low $(\approx 11 \%)$, but apparently some stratification was beneficial for osha seed germination. Germination was similar with the remaining three treatments, averaging $0.9 \%$ (treatment $1=0 \%$, treatment $2=$ $0.8 \%$, treatment $3=1.8 \%$ ).

Although some seeds in the Apiaceae show enhanced germination in the presence of light, particularly at lower temperatures (Rubatzky et al., 1999), this was not observed in the current study as no differences occurred between percent emergence in light on the mist bench and in dark in the germination chamber. There was also no difference between the mist bench and germination chamber as days to first emergence 
Table 1. Analysis of variance for detached seeds (Expt. 1) and seeds attached to umbels (Expt. 2) for percent emergence of osha (Ligusticum porteri) seeds using four cold treatments and two germination techniques.

\begin{tabular}{lccc}
\hline & Expt. 1 & & Expt. 2 \\
\cline { 2 - 3 } Source & Detached seeds & & Seeds attached to umbels \\
\hline Cold, moist treatment ${ }^{z}$ & $* *$ & $*$ \\
Germination technique $^{y}$ & NS & & NS \\
Treatment $\times$ technique & NS & & $*$ \\
\hline
\end{tabular}

${ }^{2}$ Cold treatments were control with no cold, moist stratification; 6 weeks cold, moist stratification at $4.4^{\circ} \mathrm{C}\left(40^{\circ} \mathrm{F}\right)$ 4 weeks cold, moist stratification at $4.4^{\circ} \mathrm{C}$ followed by transfer to a germination chamber for 4 weeks at alternating $12 \mathrm{~h}$ at $30.0^{\circ} \mathrm{C}\left(86^{\circ} \mathrm{F}\right)$ and $12 \mathrm{~h}$ at $20.0^{\circ} \mathrm{C}\left(68^{\circ} \mathrm{F}\right)$; or 12 weeks cold, moist stratification at $4.4^{\circ} \mathrm{C}$.

Germination techniques were germination chamber in the dark alternating $12 \mathrm{~h}$ at $30.0^{\circ} \mathrm{C}$ and $12 \mathrm{~h}$ at $20.0^{\circ} \mathrm{C}$, or mist propagation bench under natural light and daylength at $21.1^{\circ} \mathrm{C}\left(70{ }^{\circ} \mathrm{F}\right)$.

$\mathrm{Ns}^{*, * * *}$ Nonsignificant or significant at $P \leq 0.05$ or 0.001 , respectively.

Table 2. Percent emergence of seeds attached to umbels of osha (Ligusticum porteri) using four cold treatments and two germination techniques.

\begin{tabular}{lccccc}
\hline & \multicolumn{5}{c}{ Cold, moist treatment ${ }^{\mathrm{y}}$} \\
\cline { 2 - 6 } Germination & \multicolumn{5}{c}{ Mean emergence (\%) } \\
\cline { 2 - 6 } technique $^{\mathrm{z}}$ & $\mathbf{1 2}$ weeks & $\mathbf{4 - 4}$ & $\mathbf{6}$ weeks & Control & LSD $_{(P \leq 0.05)}$ \\
\hline Germination chamber & 2.7 & 0.9 & 12.8 & 0.0 & 8.1 \\
Propagation bench & 9.7 & 0.5 & 1.1 & 0.0 & \\
\hline
\end{tabular}

${ }^{2}$ Germination techniques were germination chamber in the dark alternating $12 \mathrm{~h}$ at $30.0^{\circ} \mathrm{C}\left(86{ }^{\circ} \mathrm{F}\right)$ and $12 \mathrm{~h}$ at $20.0^{\circ} \mathrm{C}\left(68^{\circ} \mathrm{F}\right)$, or mist propagation bench under natural light and daylength at $21.1^{\circ} \mathrm{C}\left(70{ }^{\circ} \mathrm{F}\right)$.

${ }^{y}$ Cold treatments were control with no cold, moist stratification; 6 weeks cold, moist stratification at $4.4{ }^{\circ} \mathrm{C}(40$ $\left.{ }^{\circ} \mathrm{F}\right) ; 4$ weeks cold, moist stratification at $4.4^{\circ} \mathrm{C}$ followed by transfer to a germination chamber for 4 weeks at alternating $12 \mathrm{~h}$ at $30.0^{\circ} \mathrm{C}$ and $12 \mathrm{~h}$ at $20.0^{\circ} \mathrm{C}$; or 12 weeks cold, moist stratification at $4.4^{\circ} \mathrm{C}$.

after 12 weeks of cooling was $1 \mathrm{~d}$ in both cases, and days to first transplant was 13 $\mathrm{d}$ in both (data not shown). Although the 12-week stratification process was lengthy, the percent emergence was higher than other treatments and the longer time may be needed.

Seed propagation-Expt. 2: Seeds attached to umbels. Cold, moist stratification treatment and germination technique interacted for effects on percent emergence (Table 1). Six weeks of stratification, with seeds transferred to a standard germination chamber, gave the highest percentage emergence (Table 2). This result was similar to 12 weeks of stratification with transfer to a propagation bench. The basis for the similarity in results with these two treatment combinations is not apparent. Emergence under all other combinations was less than with the two previous treatments and averaged $<1 \%$.

Vegetative propagation-Expt. 3: Crown cuttings. New roots were visible $6 \mathrm{~d}$ after planting. Thirty-three days after cuttings were stuck, $90 \%$ of the cuttings had rooted sufficiently to be transplanted. The remaining 10\% did not root and were discarded.

Vegetative PROPAGATION-EXPT.4: Root cuttings. Propagation of osha via root cuttings was not successful as no cuttings formed roots or shoots. This was due to rotting of cuttings on the mist bench.

\section{Discussion}

In this study the highest level of germination of detached seeds occurred after 12 weeks of cold, moiststratification at $4.4{ }^{\circ} \mathrm{C}$. Seeds attached to umbels also responded to stratification as 6 weeks of cold, moist treatment followed by the germination chamber, and 12 weeks of cold, moist treatment followed by placement on the mist bench, gave the highest percent emergence. However, emergence percentages were very low with all treatments indicating difficulties with mass propagation of osha using seeds. Seed priming and/or treatment with gibberellic acid to help overcome dormancy might improve success. Some Apiaceae members have linear embryos that take up about half the length of seeds. With this type of seeds, treatment with gibberellic acid and warm germination temperatures $\left(>20.0^{\circ} \mathrm{C}\right)$ enhanced germination (Hartmann et al., 2002).

It is possible that using fresh seed, sowing it and stratifying it immediately, would improve results. Propagation through seed requires timely collection of mature, viable seeds. The viability of the seed lots used in this study was $\approx 50 \%$ and it is uncertain whether this was typical or due to loss of viability during storage before use. Nevertheless, relative to controls, $\approx 23 \%$ of viable seed germinated.

Umbels were prone to rotting on the propagation bench and seedlings were difficult to separate for transplanting. Reasons for the increase in germination after 6 weeks of cooling followed by placement in the germination chamber, compared to results with detached seeds, are unclear. It is possible that the seeds attached to the umbels were more physiologically developed.

Propagation of osha via crown cuttings is probably the most useful method of obtaining mature plants. Crown cuttings were easy to take and stick in media and could be transplanted within 5 weeks. These cuttings were taken in the spring; cuttings taken at other times of the year may show different rooting success. Removing roots from the wild, however, will still lead to loss of germplasm, so multiplication of crowns would have to be performed using nursery-maintained stock.

Plants grown successfully from seeds and crown cuttings in this study are currently growing in the field for stock plants. Studies are being conducted to improve seed stratification and crown cutting procedures.

\section{Literature cited}

Beck, J.J. and F.R. Stermitz. 1995. Addition of methyl thioglycolate and benzylamine to $(\mathrm{Z})$-ligustilide, a bioactive unsaturated lactone constituent of several herbal medicines: An improved synthesis of (Z)-ligustilide. J. Natural Products 58:1047-1055

Bergner, Paul. 1994. Top herbs in medical practice. Medical Herbalism 6:8-9.

Dorn, R.D. 1992. Vascular plants of Wyoming. $2^{\text {nd }} \mathrm{ed}$. Mountain West Publ., Cheyenne, Wyo.

Ellis, R.H., T.D. Hong, and E.H. Roberts. 1985. IBPGR handbooks for genebanks. no. 3. vol. 2. Compendium of specific germination information and test recommendations. Intl. Board Plant Genet. Resour., Rome.

Gillespie, S. 1996. Ligustilides. The Herbalist. (August): $12-13$

Gillespie, S. 1998. Phthalides and monoterpines of the hexane extracts of the roots of Ligusticum porteri, L. filicinum and $L$. tenuifolium. Planta Medica 64:392.

Hartmann, H.T., D.E. Kester, F.T. Davies, Jr., and R.L. Geneve. 2002. Plant propagation: Principles and practices. $7^{\text {th }}$ ed. Prentice Hall, Upper Saddle River, N.J.

Maynard,D.N. and G.J. Hochmuth. 1997. Knott's handbook for vegetable growers. $4^{\text {th }}$ ed. Wiley, New York.

Moore, M. 1995. Los remedios. Red Crane Books, Santa Fe, N.M.

Plant Conservation Alliance. 2000. Green medicine. 28 Aug. 2003. <http://www.nps.gov/plants/medicinal/>

Plant Conservation Alliance. 2002. Osha. 28 Aug. 2003 <http://www.nps.gov/plants/medicinal/plants/ligusticum_porteri.htm>

Rubatzky, V.E., C.F. Quiros, and P.W. Simon. 1999. Carrots and related vegetable Umbelliferae. CABI Publ., New York. United Plant Savers. 2000. UPS “At Risk” Forum. 28 Aug. 2003. <http://unitedplantsavers.org/index.php? module $=\mathrm{C}$ ontentExpress\&func $=$ display\&ceid $=6>$

University of Maryland. 1999. Graduate Program in Sustain able Development and Conservation Biology. Proposal for the listing of Ligusticum porterito Appendix II of the Convention on International Trade in Endangered Species of Wild Fauna and Flora. U.S. Fish and Wildlife Service Office of Scientific Authority. December. 28 Aug. 2003. <http://www.nps.gov/ plants/medicinal/pubs/cites-a.htm\#lib_bio>.

Zand, J., R. Walton, and R. Roundtree. 1994. Smart medicine for a healthier child. Avery Publ. Group, Garden City Park, N.Y. 